\title{
COMPARISON OF VARIOUS TYPES OF DAMAGE SYMPTOMS IN THE TASK OF DIAGNOSTIC COMPOSITE PROFILES
}

\author{
Damian MARKUSZEWSKI \\ Department of Fundamentals of Machine Design and Operation, Institute of Machine Design Fundamentals, \\ Faculty of Automotive and Construction Engineering, Warsaw University of Technology, Poland \\ damian.markuszewski@pw.edu.pl
}

Abstract

The current trend of weight reduction entails a reduction in safety factors. This approach is understandable, but light profiles are more susceptible. The structure works close to the boundary loads, and their destruction is primarily determined by dynamic relief. Today, composite masts are diagnosed by the following methods: optical microscopy, electron microscopy, X-ray analysis and thermal analysis. These methods are invasive methods. It seems that the vibration analysis of the mast - rigging system could supplement or replace the mentioned methods without the need to dismantle the mast, giving the possibility of testing on the yacht [5]. The article presents the possibility of diagnosing a composite material defect on the example of a interrupts a continuity of structure.

Keywords: vibrations, composite materials, diagnostic symptom, modern mast.

\section{PORÓWNANIE RÓŻNEGO RODZAJU SYMPTOMÓW USZKODZENIA W ZADANIU DIAGNOZOWANIA PROFILI KOMPOZYTOWYCH}

Streszczenie

Obecna tendencja do redukcji masy pociąga za sobą obniżenie współczynników bezpieczeństwa. Takie podejście jest zrozumiałe, ale lekkie profile są bardziej podatne. Konstrukcja pracuje blisko obciążeń granicznych, a o ich zniszczeniu decydują przede wszystkim odciążenia dynamiczne. Współcześnie maszty kompozytowe diagnozuje się następującymi metodami: mikroskopii optycznej, mikroskopii elektronowej, analizy rentgenowskiej i analizy termicznej. Wymienione metody są metodami inwazyjnymi. Wydaje się, że analiza drgań układu maszt - olinowanie mogłaby uzupełnić lub zastąpić wymienione metody bez potrzeby demontażu masztu, dając możliwość wykonania testu na jachcie [5]. W artykule przedstawiono możliwość diagnozowania defektu materiału kompozytowego, polegającego na przerwaniu ciągłości struktury osnowy.

Słowa kluczowe: drgania, materiały kompozytowe, symptom diagnostyczny, maszt jachtowy.

\section{INTRODUCTION}

The worldwide tendency to minimize the weight of the construction and setting new records forces the constructors to use the best available components and technologies.

An example of a modern construction material that has been used for high-performance sailing sports is a carbon composite with aramid and epoxy resin filler [7], [8], [19].

In contrast to many other classic solutions, the profile made of such a material guarantees high short-term and fatigue strength as well as the possibility of obtaining selective stiffness with minimization of mass, without changing geometrical dimensions [18]. During work, additional mast stabilization is provided by shrouds (Fig. 1).

Except many listed advantages, this kind of material also has disadvantages. Any material defect (microcarb or microcracks, discontinuity of the warp structure, delamination and high temperature sensitivity [12]) poses a threat of accelerated destruction of the structure. Therefore, diagnostics of this type of objects is of key importance in high-performance sport [6].

The main difficulty is the fact that nonaxisymmetric composite structures are non-linear, which requires each time to carry out a rather labour-intensive modeling process [2], [9], [10], [11], [17].

The article presents the possibility of diagnosing a composite material defect on the example of a interrupts a continuity of structure. A good example is the anchorage of the salling.

The most dangerous point of the mast is construction hole made for saling. This hole interrupts the structure of comoposite and can damage the construction.

During operation, under the influence of dynamic deformations diameter of the hole increases. Damage is propagated. An additional 
difficulty is the fact that the hols are covered by salling.

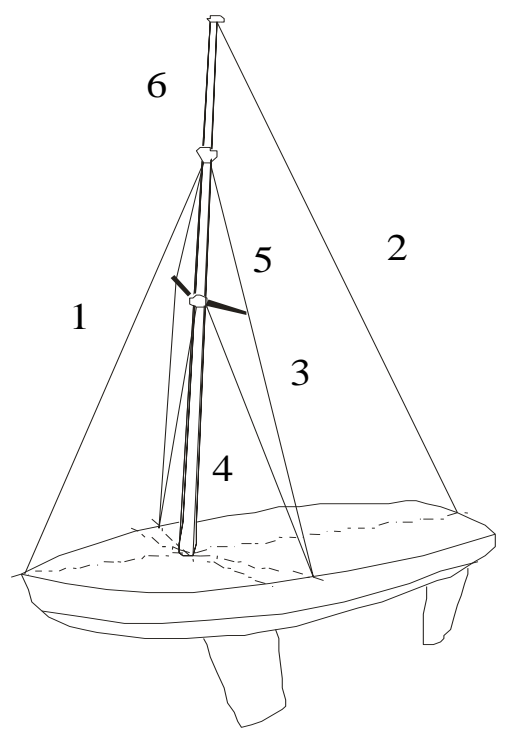

Fig. 1. Example of rigging a small yacht economical option [3]: 1 - stay, 2 - backstay,

3 - shrouds, 4 - intermediate shrouds, 5 - salling, 6 - mast

The load is the result of the action of a complex system of forces, which includes, among others: bending moment, Disassembly of the mast and fittings is very expensive. There is a real need to use diagnostics of this type of objects, giving information about existing defects of the structure, and, above all, information about developing damage during operation.

\section{RESEARCH STATION}

This mechanism was recreated by intentionally enlarging the diameter of the technological hole. A experiment was carried out on the research stand. A model section of the mast with a length of 3000 $\mathrm{mm}$ is equipped with a salling ${ }^{1}$ with the possibility of adjusting the angle of working (Fig. 2).

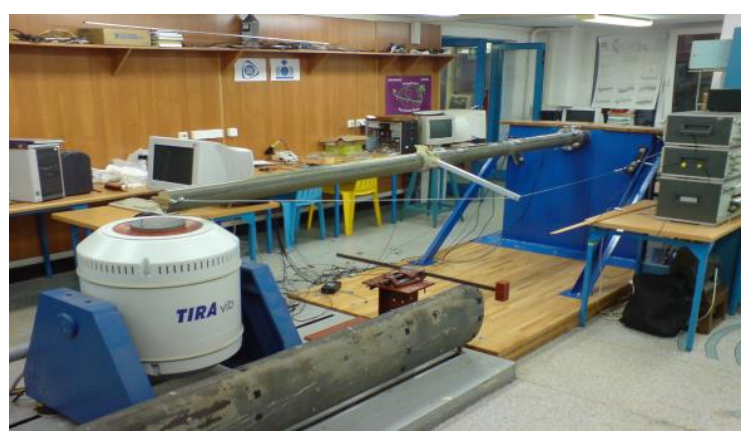

Fig. 2. Measurement and research stand

\footnotetext{
${ }^{1}$ Salling - rigid spacer increasing the angle between fixed rigging and the mast.
}

The use of such a system enables tensioning the shroud, which stabilizes the mast and increases the stiffness of the system and introduces bending moment. Adjustment of the working angle of the salling (Fig. 3) may result in a greater initial curve of the mast [1].

The object of the experiment was an elliptical mast mounted in the bracket. As the tensioning force increases, the mast bends towards the operation of the salling. The experiment uses a short-time force impulse with a modal hammer. The mast was analyzed as a beam with a complex crosssection, fading vibrations were observed.

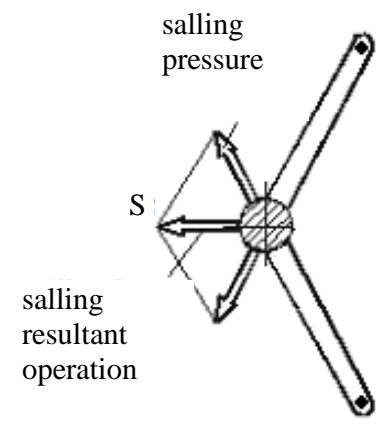

Fig. 3. System: mast - salling [4]

In the response spectra analyzed, three important components can be distinguished: bending vibrations, vibrations of the cross-section and vibrations of the surface layer. The study shows the relationship between the deformation of the surface layer, and velocity of vibrations. For this purpose, synchronous recording of the signals was made: deformation of the surface layer of the composite using the HBM LY10 extensometer and vibration acceleration in the direction perpendicular to the mast using a B \& K 4514 accelerator at several points on the mast (Fig. 4).

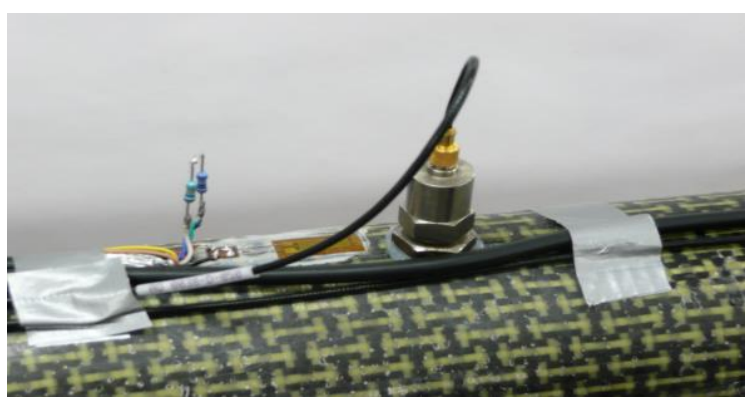

Fig. 4. Sample measuring point

\section{EXPERIMENT}

Based on the recorded dynamic signals, an attempt was made to find various types of diagnostic symptoms. The symptoms examined individually were presented in [13], [14], [15], [16]. These studies show that the most effective way to look for a symptom of damage is to select a characteristic band and apply a suitably chosen 
method depending on the boundary conditions: type of force, type of support, selection of the measuring point, selection of tensioning force, setting of the shuttering, selection of the fixing point.

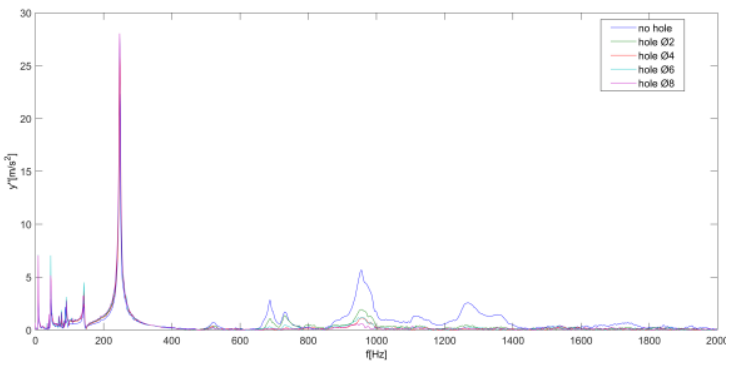

Fig. 5. The acceleration of vibration spectrum for the forced impulse at the selected tensioning force $400 \mathrm{~N}$ of the shrouds

Figure 5 presents the selected spectrum of vibration accelerations. Four frequencies of $7 \mathrm{~Hz}$, $247 \mathrm{~Hz}, 685 \mathrm{~Hz}$, and $960 \mathrm{~Hz}$ can be observed. The level of the signal components at these frequencies changes monotonically as the diameter of the hole increases. The amplitudes of the frequencies $7 \mathrm{~Hz}$, $247 \mathrm{~Hz}$ take on increasing values, while $685 \mathrm{~Hz}$, $960 \mathrm{~Hz}$ frequencies are getting lower values. The frequencies $7 \mathrm{~Hz}, \quad 247 \mathrm{~Hz}$ represent bending vibrations and are particularly useful in assessing vibrations due to the maximum values of accelerations. However $685 \mathrm{~Hz}, 960 \mathrm{~Hz}$ frequencies represent vibrations of the surface layer.

\section{RESULTS}

The diagrams presented in figures 6-9 show changes in the values of the amplitudes of $7 \mathrm{~Hz}$, $247 \mathrm{~Hz}, 685 \mathrm{~Hz}$ and $960 \mathrm{~Hz}$, with the increase of the diameter of the hole for the different tensioning force of the shrouds. In order to present information in a form that is convenient for interpretation, a linear trend (least-squares method) is additionally included.

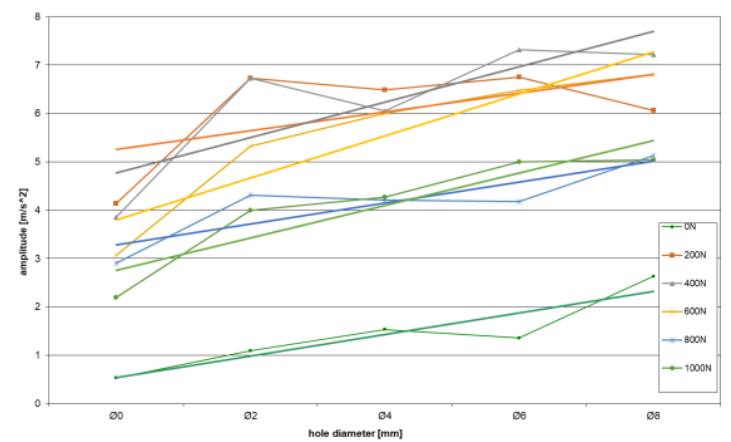

Fig. 6. Change in the amplitude of vibration accelerations with a frequency component of $9 \mathrm{~Hz}$ in the function of the enlarging hole with different tensioning forces of the shrouds

For knowing properties of the object, it is better to apply kinematic extortion, i.e. deflection from the equilibrium position, while for the detection of the defect dynamic impulse, i.e. a short-lasting impulse of force. You can also observe the energy flow between individual components.

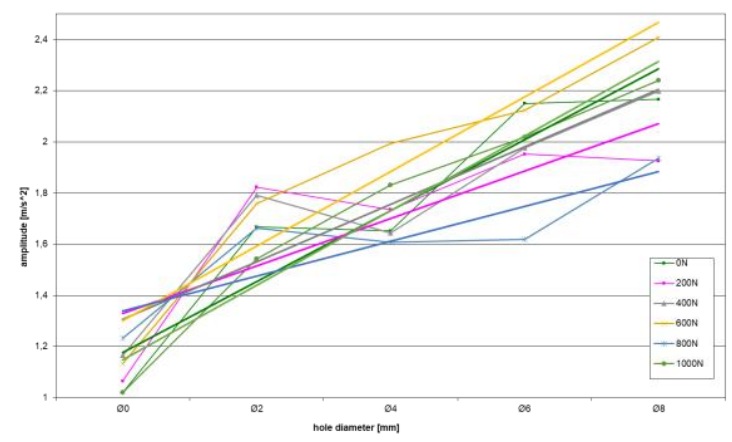

Fig. 7. Change in the amplitude of vibration accelerations with a frequency component of $247 \mathrm{~Hz}$ in the function of the enlarging hole with different tensioning forces of the shrouds

The obtained results have a moderate dispersion, but are difficult to interpret due to the complex vibration mechanism of the composite structure. The results depend on many variables, e.g. Young's modulus, which changes with the deformation speed and we can only take substitute value.

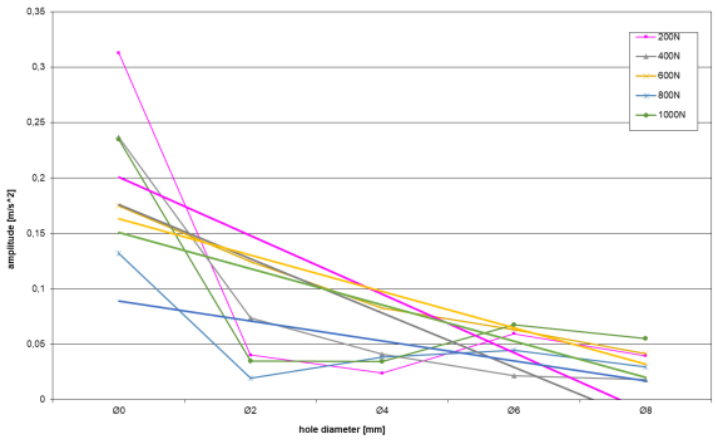

Fig. 8. Change in the amplitude of vibration accelerations with a frequency component of $685 \mathrm{~Hz}$ in the function of the enlarging hole with different tensioning forces of the shrouds

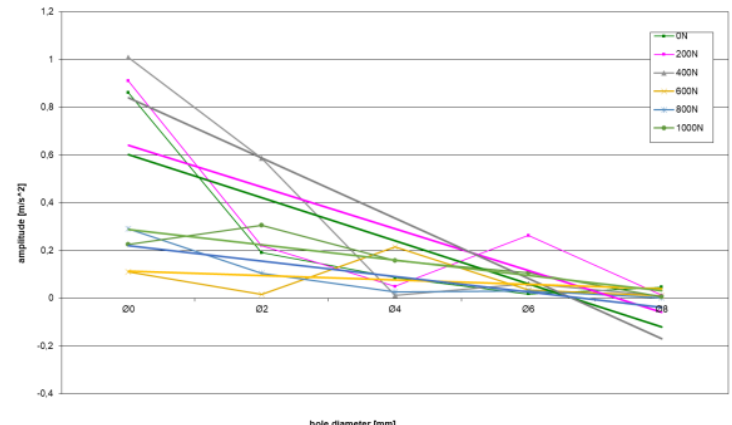

Fig. 9. Change in the amplitude of vibration accelerations with a frequency component of $960 \mathrm{~Hz}$ in the function of the enlarging hole with different tensioning forces of the shrouds

Based on the measurements, a test was proposed that identifies the failure, i.e. detects a change in the 
diameter of the structural opening in the mast. Based on the observation of the composite surface layer deformation and vibration acceleration - phase trajectories (Fig. 10) have been drawn which can be used in the diagnostic test.

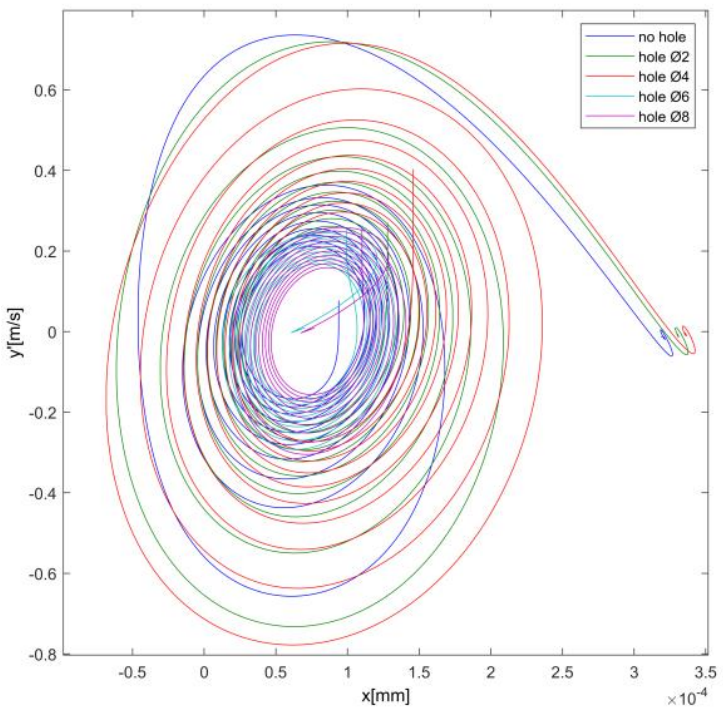

Fig. 10. An example of a quasi-phase trajectory for $400 \mathrm{~N}$ tensioning force of the shrouds

It can be observed on the trajectories that as the load increases, trajectories move to the right, positive deformations - stretching. The shift results from the increase of mast deformation, the profile is pushed towards the stay by means of the arrangement of the salling and shrouds. Another observation that can be noticed by looking at subsequent trajectories is the rotation with the increase in the diameter of the hole to the right.

For further analysis, well-known relationships were used, i.e. the moment of inertia of the flat figure relative to the $X$ axis (1), i.e. the sum of the product of the elementary products of the fields $\mathrm{dF}$ and the squares of the distance of these fields from the $\mathrm{X}$ axis:

$$
J_{X}=\int_{F} x^{2} d F
$$

and that the centrifugal moment of inertia of the figure (2) is the expression, which is the sum of the products of the fields $\mathrm{dF}$ and the distance of the centers of gravity of these fields from the $\mathrm{x}$ and $\mathrm{y}$ axes.

$$
J_{X Y}=\int_{F} x y d F
$$

As we already know, the centrifugal moment of inertia can be positive and negative or set to zero. For the last case, the axes will be called the main axes of the section. If the axis of the coordinate system is the axis of symmetry of the figure, then the centrifugal moment of inertia relative to such axis is zero and such axis is the main axis. So axes with respect to which moments of inertia will reach extreme values are called main axes, and moments of inertia with respect to such axes are main moments of inertia. In order to determine the direction of the axis at which the moment of inertia relative to it reaches the extreme, it is necessary to use the relationship (3):

$$
\operatorname{tg} 2 \alpha=\frac{2 J_{X Y}}{J_{Y}-J_{X}}
$$

where $\alpha$ - is the sought trajectory rotation angle.

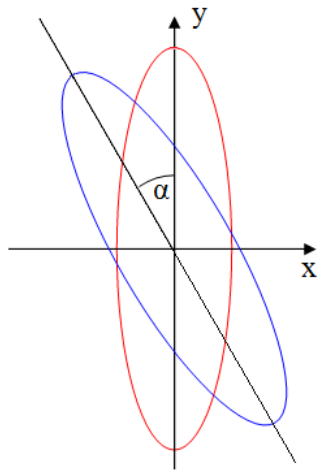

Fig. 11. Rotation angle of the main axes of inertia sought

The trajectory rotation angle characteristics were plotted against the enlarging diameter of the hole (Fig. 11). In order to present information in a convenient form for interpretation, a linear trend is additionally included.

On the measurements and analyzes it can be clearly stated that along with the increase of the rigging tension the value of the acceleration accelerations of the $7 \mathrm{~Hz}$ and $247 \mathrm{~Hz}$ amplitudes increases, and thus the slope of the characteristic curve increases (Fig. 6). This results in increased selectivity of the symptom of damage for rigging tension $400 \mathrm{~N}, 600 \mathrm{~N}$ and $1000 \mathrm{~N}$ (Fig. 13). On the other hand, the amplitudes acceleration of vibration for $685 \mathrm{~Hz}$ and $960 \mathrm{~Hz}$ frequency is monotonously decreasing, and the slope of the characteristic curve decreases. The disadvantage of this method is vefy high sensitivity to errors of mounting 1 ) and introduction of extortion.

The second technique of seeking damage to the structure of the composite shows the reverse tendency, along with the increase tensioning forces of the shrouds (Fig. 14), the characteristics representing the angle of rotation (Fig. 12) of the trajectory are flattering due to the increase of the initial bending of the mast, and by it increases stiffness. Despite this, the symptom of damage is more selective in the whole range of changes in the tensioning forces of the shrouds, but the relationship between speed and the displacement is less sensitive to errors of mounting and introduction of extortion. 


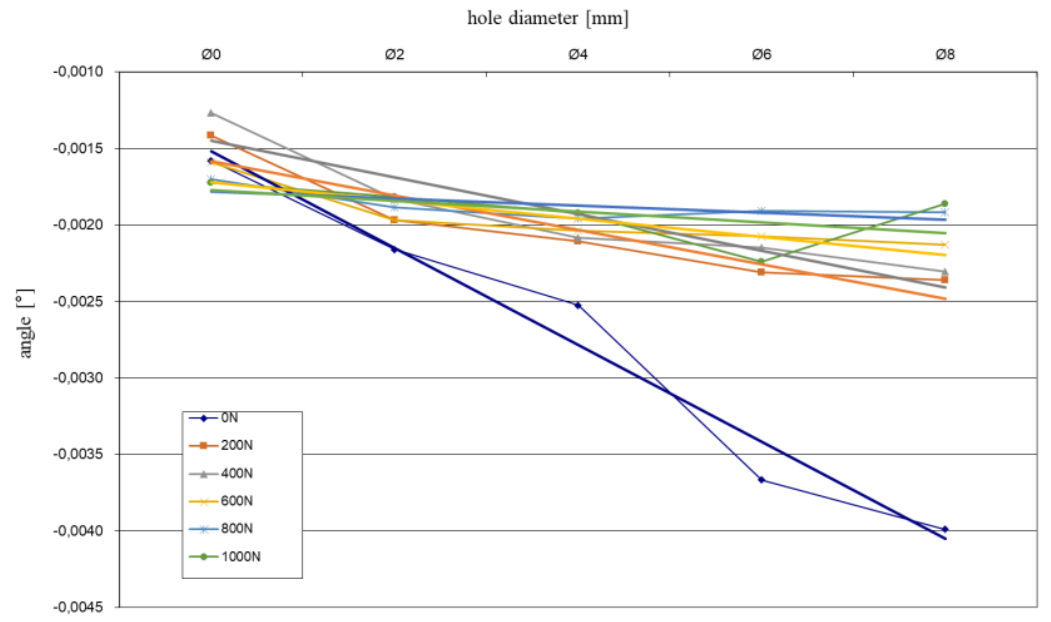

Fig. 12. The angle of rotation (Fig.11) of the quasi phase path in the function of the expanding hole for different tensioning forces of the shrouds

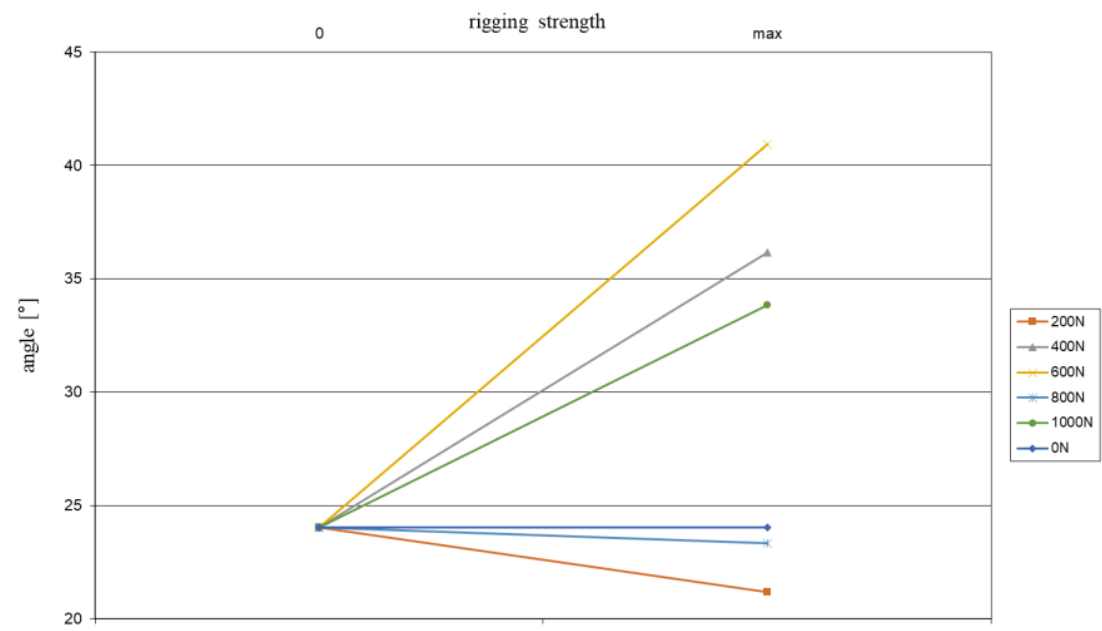

Fig. 13. Changing the angle of the trend of the symptom based on the acceleration of vibrations for the $9 \mathrm{~Hz}$ component with different tensioning forces of the shrouds

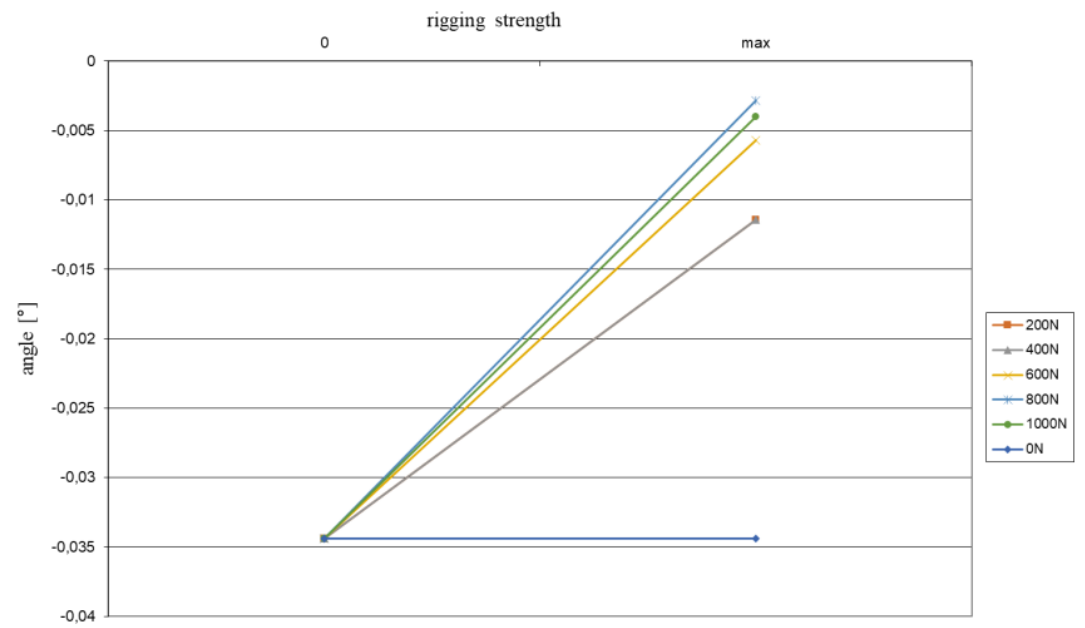

Fig. 14. Changing the angle of the symptom slope based on the angle of rotation (Fig. 11) of the trajectory for the $9 \mathrm{~Hz}$ component with different tensioning forces of the shrouds 


\section{CONCLUSION}

Over the next few years, the main criterion for optimizing all types of yachts will be to minimize the weight of masts and the number of ropes and stiffeners in the form of sails and strength conditions will be treated as functional limitations. Mechanical vibrations, which problem in the case of rigid wooden masts or metal did not exist, can be used as a diagnostic symptom.

Both symptoms are effective for looking changes in the structure of a composite material, but when selecting a symptom for a particular unit, it is necessary to take into account the tuning of its accessories ("rigid" or "loose") taking into account the load and predicted measurement conditions.

\section{REFERENCES}

1. Batko W, Dąbrowski Z, Engel Z, Kiciński J, Weyna $S$. Nowoczesne metody badania procesów wibroakustycznych. cz. I, ITE - PIB, 2005.

2. Batko W, Dąbrowski Z, Kiciński J. Nonlinear effects in technical diagnostics. PAN - ITE-PIB, 2008.

3. Batko W, Dąbrowski Z. Nowoczesne metody badania procesów wibroakustycznych (zastosowania techniczne). cz. II", ITE - PIB, 2006.

4. Dąbrowski Z, Dziurdź J, Skórski WW. Drgania masztów kompozytowych; Wydawnictwo ITE - PIB, 2007.

5. Dąbrowski Z, Dziurdź J, Skórski WW. Próba analizy stanu profili kompozytowych metodami wibroakustycznymi. XXIX Sympozjum Diagnostyki Maszyn, 2002.

6. Dąbrowski Z, Maryniak J, Skórski WW. Elementy dynamiki jachtu żaglowego. Wydawnictwo Instytutu Technologii Eksploatacji, 2001.

7. Dąbrowski Z, Maryniak J, Skórski WW. Nowoczesne metody obliczeniowe i badawcze w projektowaniu jachtów żaglowych. Wydawnictwo Instytutu Technologii Eksploatacji, 2002.

8. Dąbrowski Z, Dziurdź J, Skorski W. fault diagnosis of carbon fibre composite masts. engineering asset management. Mathew Joseph [i in.] (red.), 2006, Springer London.

9. Dąbrowski Z, Deuszkiewicz P, Dziurdź J. Modelling of composite elements of power transmission systems considering nonlinear material characteristics. Problemy Eksploatacji. Maintenance Problems. 2018; 3:87-94.

10. Dąbrowski Z, Deuszkiewicz P. Designing of HighSpeed Machine Shafts of Carbon Composites with Highly Nonlinear Characteristics", Key Engineering Materials. 2012;490: 76-82. https://doi.org/10.4028/ www.scientific.net/KEM.490.76.

11. Dąbrowski Z, Deuszkiewicz P. Dynamic model of carbon fiber drive shaft, Solid State Phenomena. 2015; 236:39-52. https://doi.org/10.4028/www. scientific.net/SSP.236.39.

12. Katunin A, Gnatowski A. Influence of heating rate on evolution of dynamic properties of polymeric laminates. Taylor \& Francis, Plastics, Rubber and Composites, 2012; 41: 223-239.

13. Markuszewski D. Laboratoryjne stanowisko do badań drgań własnych masztów kompozytowych. XIII Konferencja Naukowa Wibrotechniki i Wibroaku- styki i VII Ogólnopolskie Seminarium pt. „Wibrotechnika w Systemach Technicznych” Jachranka, 2007.

14. Markuszewski D. Wpływ kąta ustawienia salingu na postacie drgań własnych masztów kompozytowych. XV Konferencja Naukowa Wibrotechniki i Wibroakustyki i VII Ogólnopolskie Seminarium pt. „Wibrotechnika w Systemach Technicznych" Sękocin Stary, 2010.

15. Markuszewski D. Trajektoria fazowa jako symptom diagnostyczny oceny stanu technicznego kompozytowej konstrukcji cienkościennej. Przegląd Mechaniczny, Instytut Mechanizacji Budownictwa i Górnictwa Skalnego. 2015;7-8:32-37.

16. Markuszewski D. Detection and tracking damage in composite structures elements. Machine Dynamics Research. 2016;40(4):10-18.

17. Skórski W, Zawisza M. Influence of the composite modification of the wooden wing skin of the glider on deflection lines and resonance vibrations. Polimery. 2019;64(4):267-271.

https://doi.org/10.14314/polimery.2019.4.4

18. Parunov J, Guedes Soares C. Trends in the analisys and design of marine structures. Taylor\& Francis Group 2019.

19. Skórski WW. Maszty kompozytowe - wdrażanie nowej technologii. Przegląd Mechaniczny, Instytut Mechanizacji Budownictwa i Górnictwa Skalnego. 2001;5:9-12

Received 2019-01-11

Accepted 2019-06-17

Available online 2019-08-20

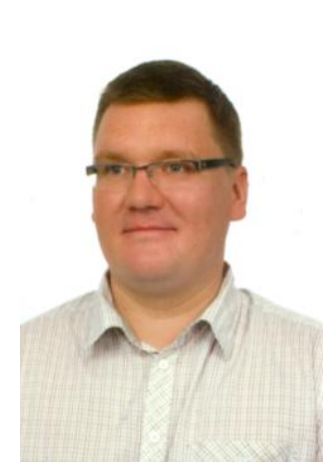

Damian MARKUSZEWSKI received $\mathrm{PhD}$ degree in Faculty of Automotive and Construction Machinery Engineering from Warsaw University of Technology, Poland, in 2013. Now he works at the same place. His current research interests include composite materials and vibroacoustic diagnostics of machines. 